\title{
Field Survey and Geological Effects of the 15 November 2006 Kuril Tsunami in the Middle Kuril Islands
}

\author{
Breanyn T. Macinnes, ${ }^{1}$ Tatiana K. Pinegina, ${ }^{2}$ Joanne Bourgeois, ${ }^{1}$ \\ Nadezhda G. Razhigaeva, ${ }^{3}$ Victor M. Kaistrenko, ${ }^{4}$ and \\ EKATERINA A. KRAVChUNOVSKAYA ${ }^{2}$
}

\begin{abstract}
The near-field expression of the tsunami produced by the 15 November 2006 Kuril earthquake $\left(\mathrm{M}_{\mathrm{w}}\right.$ 8.1-8.4) in the middle Kuril Islands, Russia, including runup of up to $20 \mathrm{~m}$, remained unknown until we conducted a post-tsunami survey in the summer of 2007. Because the earthquake occurred between summer field expeditions in 2006 and 2007, we have observations, topographic profiles, and photographs from three months before and nine months after the tsunami. We thoroughly surveyed portions of the islands of Simushir and Matua, and also did surveys on parts of Ketoi, Yankicha, Ryponkicha, and Rasshua. Tsunami runup in the nearfield of the middle Kuril Islands, over a distance of about $200 \mathrm{~km}$, averaged $10 \mathrm{~m}$ over 130 locations surveyed and was typically between 5 and $15 \mathrm{~m}$. Local topography strongly affected inundation and somewhat affected runup. Higher runup generally occurred along steep, protruding headlands, whereas longer inundation distances occurred on lower, flatter coastal plains. Sediment transport was ubiquitous where sediment was availabledeposit grain size was typically sand, but ranged from mud to large boulders. Wherever there were sandy beaches, a more or less continuous sand sheet was present on the coastal plain. Erosion was extensive, often more extensive than deposition in both space and volume, especially in areas with runup of more than $10 \mathrm{~m}$. The tsunami eroded the beach landward, stripped vegetation, created scours and trim lines, cut through ridges, and plucked rocks out of the coastal plain.
\end{abstract}

Key words: Tsunami, Kuril Islands, coastal geomorphology, tsunami deposit, tsunami erosion.

\section{Introduction}

A pair of tsunamigenic great earthquakes occurred seaward of the middle Kuril Islands in November 2006 and January 2007—one of the largest earthquake doublets on record (Aмmon et al., 2008). The 2006 earthquake occurred along the plate boundary,

\footnotetext{
${ }^{1}$ Department of Earth and Space Sciences, University of Washington, Seattle, WA 98195, USA. E-mail: macinneb@u.washington.edu

${ }^{2}$ Institute of Volcanology and Seismology, Far Eastern Branch Russian Academy of Sciences, 683006 Petropavlovsk-Kamchatskiy, Russia.

${ }^{3}$ Pacific Institute of Geography, Far Eastern Branch Russian Academy of Sciences, 690041 Vladivostok, Russia.

${ }^{4}$ Institute of Marine Geology and Geophysics, Far Eastern Branch Russian Academy of Sciences, 693022 Yuzhno-Sakhalinsk, Russia.
} 
whereas the 2007 earthquake was produced by normal faulting on the outer rise, similar to the interpreted source of the 1994 Shikotan earthquake (HARADA and IsHIBASHI, 2007, and earlier references).

Everywhere the 2006 and 2007 Kuril tsunamis were measured, the 2006 tsunami was larger (National Geophysical Data Center, NGDC database). Moreover, the 1994 Shikotan tsunami was an average of 1.5 times larger than the 2007 tsunami on transPacific tide gages (NGDC database). The records in the database, as well as arguments we make herein, lead us to interpret our surveyed tsunami effects in the middle Kurils as the product of the 2006 tsunami.

The 15 November 2006 middle Kurils tsunami was widely reported in the media to be small, a report based principally on its early expression in northern Japan, where later tsunami waves had tide-gage water heights ${ }^{1}$ reaching $0.6 \mathrm{~m}$. Tide-gage heights in Hawaii ranged up to $0.76 \mathrm{~m}$, and on the far side of the Pacific, in Crescent City, California, a 0.88$\mathrm{m}$-high wave (1.76 m peak to trough) generated $\$ 700,000-\$ 1$ million worth of damage (Kelly, 2006) in the harbor. Tide-gage records from the southern Kurils include maximum water heights of about $0.8 \mathrm{~m}$ (Sakhalin Tsunami Warning Center), however, there are no stations in the middle Kurils. Local runup for this tsunami remained unknown until our surveys in summer of 2007 (preliminary results reported in LEVIN et al., 2008). No one lives in this remote area and logistics for visiting the islands are complex and expensive.

Two expeditions sponsored by the Institute of Marine Geology and Geophysics, Yuzhno-Sakhalinsk, Russia (IMGG) and the NSF-funded Kuril Biocomplexity Project (KBP) worked together in the middle Kurils in July and August 2007, to survey inundation, runup and geomorphic effects of the 2006 tsunami. Inundation and runup are standard descriptions of tsunami size and report the tsunami's maximum inland distance and the elevation of that position, respectively, for any given stretch of coastline (FARRERAS, 2000). Surveys of geomorphic impacts of tsunamis are less standardized and can include field descriptions or measurements of erosion, deposits, and other tsunami effects. In 2007, a total of four working groups documented tsunami effects at 130 locations in 11 bays, over a distance of about $200 \mathrm{~km}$, along the rupture zone of the 15 November 2006 and 13 January 2007 earthquakes. Several members of the 2007 expeditions, including most of the authors, had surveyed parts of these islands in the summer of 2006, under the aegis of the KBP. Our prior surveying provided a remarkable opportunity to make direct measurements and comparisons, at the same time of year, of shorelines before and after the tsunamis.

\section{15 November 2006 and 13 January 2007 Earthquakes and Tsunamis}

The two middle Kuril great earthquakes of 2006 and 2007 filled a seismic gap (Fig. 1). Previously, a large earthquake had not occurred in the middle Kurils Islands in at

\footnotetext{
1 "Water height" is the term used in the NGDC catalogue for vertical deviation from zero, which is approximately equal to amplitude, which in turn is half the trough-to-peak wave height.
} 


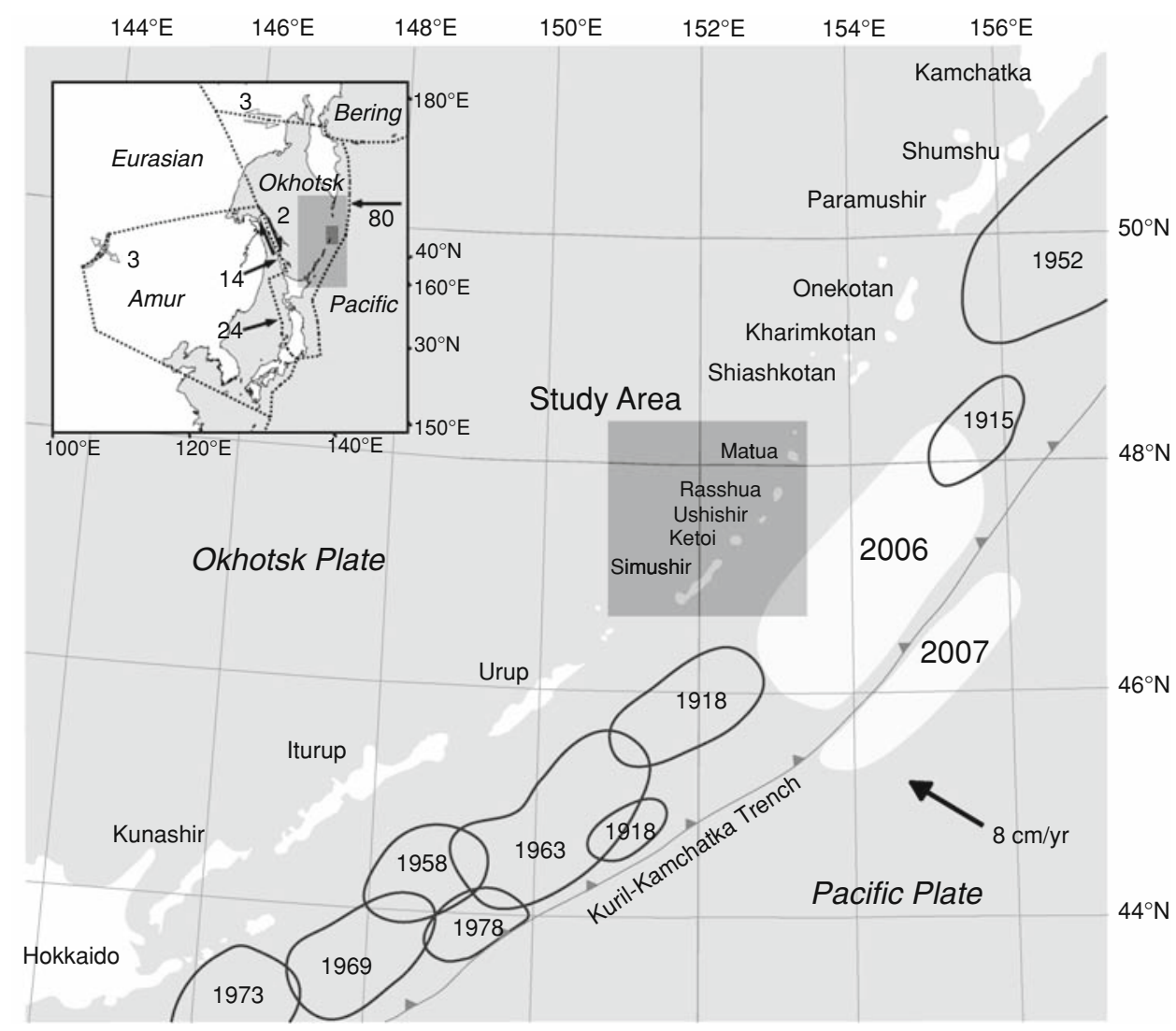

Figure 1

Tectonic setting of the Kuril Islands. Includes all historical tsunamigenic earthquakes with known source regions. Inset in the upper left: Plate tectonic map of the region including plate motions, after ApEL et al. (2006). Measured plate motions are in $\mathrm{mm} / \mathrm{yr}$.

least 150 years - a previous event believed to have occurred along the middle Kurils (LAVERov et al., 2006), was an earthquake and tsunami experienced by Captain Snow off Simushir Island in 1780 (SNOw, 1910). The region had been interpreted as a seismic gap by Fedotov as early as 1965 . However, there had been recent speculation as to whether this segment was slipping quietly (e.g., Kuzin et al., 2001; Song and Simons, 2003). Our paleotsunami field studies in the summers of 2006 and 2007 agree with the seismic-gap hypothesis (see below), as also confirmed by the recent earthquake doublet.

The 2006 earthquake released more total energy and lasted longer, whereas the 2007 earthquake had a higher peak energy release (AMmon et al., 2008). The 15 November 2006 earthquake commenced at 11:14 UTC, according to the U.S. Geological Survey, at a depth of $\sim 30 \mathrm{~km}$ on the subduction zone. The epicenter for 2006 was off Simushir Island, and propagation proceeded northward (Ji, 2006; VALlÉE, 2006; YAGI, 2006). The 
13 January 2007 earthquake, which commenced at 04:23 UTC at a crustal depth of $\sim 10 \mathrm{~km}$, was a normal-faulting, outer-rise event on the Pacific Plate, directly east of the Kuril-Kamchatka trench (JI, 2007; VALLÉE, 2007; YAGI, 2007). According to the U.S. Geological Survey, the epicenter was approximately $100 \mathrm{~km}$ ESE of the 2006 event. Global CMT solutions record the 2006 event as a $M_{W} 8.3$ and the 2007 event as a $M_{W}$ 8.1, although analysis of tsunami waveform inversions by FuJI and SATAKE (2008) suggest that $\mathrm{M}_{\mathrm{W}} 8.1$ and $\mathrm{M}_{\mathrm{W}} 7.9$ for 2006 and 2007, respectively, are more appropriate. Ammon et al. (2008) calculate $\mathrm{M}_{\mathrm{W}} 8.4$ for 2006 and $\mathrm{M}_{\mathrm{W}} 8.1$ for 2007 based on source radiation characteristics.

Both the 2006 and 2007 earthquakes produced measurable tsunamis around the Pacific Rim, although 2007 was smaller at every reported location. Observations from 113 locations for the 2006 event, and 35 locations for 2007, are archived in the National Geophysical Data Center (NGDC), Global Tsunami Database, and a few non-overlapping points in the Novosibirsk Tsunami Laboratory (NTL) Historical Tsunami Database. ${ }^{2}$ Reported 2006 tide-gage water heights range from $<0.1 \mathrm{~m}$ at several locations to values of 0.4 to $0.9 \mathrm{~m}$ at some stations in the southern Kurils, Japan, New Zealand, Chile, the Marquesas, Hawaii, the West Coast of the U.S., and the Aleutians. Of the records of the 2007 tsunami, the maximum reported tide-gage water heights are about $0.4 \mathrm{~m}$ at Malokurilsk (RABINovich et al., 2008) and Chichijima Island, $\sim 0.3 \mathrm{~m}$ at Shemya in the Aleutians, and $\sim 0.25 \mathrm{~m}$ at Port Orford and Crescent City, U.S.A. The closest measurements of the 2007 Kuril tsunami on a directed path of the earthquake, in Hawaii, are an average of 3.5 times less than those of the 2006 Kuril tsunami.

\section{Neo-Tectonic and Geomorphic Setting}

The Kuril Islands are a volcanic arc associated with subduction of the Pacific Plate under the Okhotsk Plate (Cook et al., 1986) along the Kuril-Kamchatka trench. Subducting crust is $\sim 100$ million years old, and the convergence rate is $8 \mathrm{~cm} / \mathrm{yr}$ (DeMets et al., 1990), excluding Okhotsk Plate motion (Apel et al., 2006). The Kuril Island chain includes more than 25 islands with roundly 30 active volcanoes and many prominent volcanic edifices (Gorshrov, 1970; Melekestsev, 1980).

The islands surveyed in both 2006 and 2007, Simushir to Matua islands (Fig. 2), are morphologically different than islands to the north and south. The middle Kurils span a $\sim 20^{\circ}$ bend in the arc and are smaller and more widely spaced than the northern and southern islands. Primarily, the middle islands are single or multiple volcanic edifices, with the most common coastline being steep sea cliffs. Study sites fall into two broad geomorphologic categories-bouldery pocket beaches or broad embayments with gravelly to sandy shorelines (Figs. 2 and 3). The coastal plain in most field locations

\footnotetext{
2 Note that the NGDC database reports water heights above zero, whereas the Novosibirsk database reports peak-to-trough wave heights. We are using only tide-gage records for this comparison.
} 


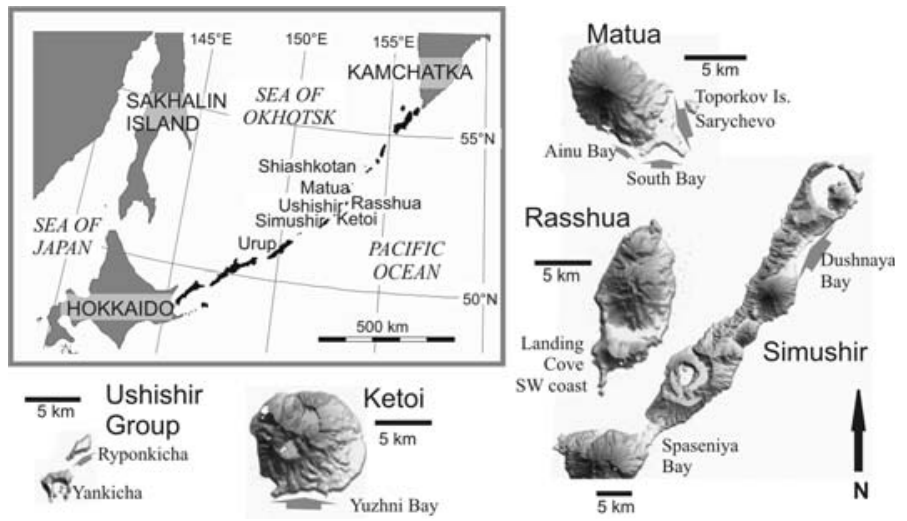

Figure 2

Overview of the basic morphology of the islands surveyed in 2007, including site names from Table 1 . The scale bar for each island is $5 \mathrm{~km}$.

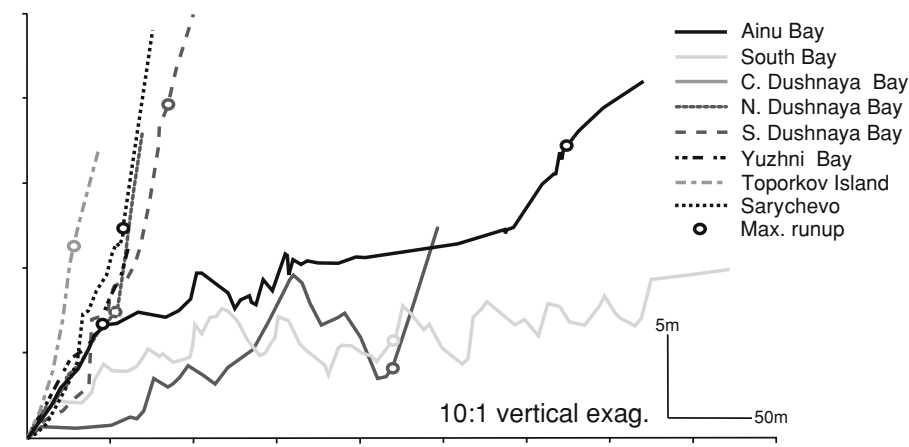

Figure 3

Example profiles that illustrate differences among short, steep coastlines (dashed lines) and broad coastal plains (solid lines). C (Central) Dushnaya Bay is an example of a profile in Table 1, where maximum runup elevation is less than the maximum elevation on the profile.

is backed by a cliff or steep slope. The largest embayments have up to $500 \mathrm{~m}$ of sandy coastal plain before this cliff, although more than half of the profiles measured were along rocky beaches with shoreline widths averaging around $50 \mathrm{~m}$ (Fig. 3).

\section{Tsunami Survey Methods}

Up to four teams operated simultaneously to measure topographic profiles, to record maximum runup and inundation, to collect tsunami-deposit samples and descriptions, and to make observations of erosion. Most sites visited in summer 2007 had been observed by team members previously, which helped us distinguish tsunami erosion and deposition 
from other processes. Newly visited localities in 2007 include Spaseniya Bay on Simushir Island and Toporkov Island off Matua Island (Fig. 2).

Except where noted in Table 1, we made all measurements with a tripod, level and rod, with an individual measurement error of $0.3 \mathrm{~cm}$ vertically and $30 \mathrm{~cm}$ horizontally. This error does not accumulate in a given segment (until the level is moved), so that cumulative vertical error is less than $30 \mathrm{~cm}$ and horizontal error generally less than a few meters; each measurement was checked for error in the field. In a few cases, we used a hand level and tape, with error of $2 \mathrm{~cm}$ vertically per measurement and about $5 \%$ error horizontally, the latter due to irregularities on the ground. Also, where slopes were steep, we converted taped measurements trigonometrically from on-the-ground to horizontal. Whenever possible, we also checked horizontal measurements with distances calculated from GPS points (Table 1).

We measured profiles to or from local sea level and in most cases corrected for tide at the time of measurement from local tide tables. Measurements were not corrected for tide at the time of the earthquake, which began about mid-tide on the flood phase, in a lowamplitude tidal cycle (less than $0.5 \mathrm{~m}$ ), based on tide tables and nearby tide gages; storm waves were active at the same time. Tidal range is typically $0.5-1.5$ meters, thus even without corrections, error in the elevation of mean sea level is slight relative to runup.

At nearly every location surveyed, we could find evidence for an inland limit of tsunami penetration. Our primary criteria for defining runup were lines of floatable debristypically driftwood, cut wood, plastic bottles and floats, glass floats, and styrofoam. In regions with short grasses and flowers, debris lines were obvious, and often one measurement accurately reflected runup. Where floated debris was obscured by this year's growing vegetation so that a debris line was not clear, we bushwacked, traced debris through the vegetation, and measured multiple points along 10-50 lateral meters. Both individual measurements and averages are reported in Table 1 and summarized in Table 2 and Figure 4. Single pieces of debris, such as one plastic bottle, were not considered adequate, as these bottles can blow in the wind. We observed some movement of debris material by animals, such as foxes, but it was rare. With the exception of southern Urup (briefly surveyed) and a small abandoned camp on Matua, we have no evidence that people had visited these islands since our visit in summer 2006. In a few cases, we measured heights of draped grass and seaweed on shrubs, but such flow-depth indicators were rare. Corroborative evidence of runup, not used independently, included the limit of consistently seaward-oriented stems of tall grasses and flowers, the limit of sand and gravel deposits on top of turf and dead vegetation, and the elevation of fresh erosion of turf.

\section{2006 or 2007 ?}

We assumed our maximum runup and inundation limits were due to the 2006, not 2007, tsunami partly based on survey and catalogue data. First, the 2007 tsunami was measured to be smaller at every catalogued location around the Pacific. At the closest 


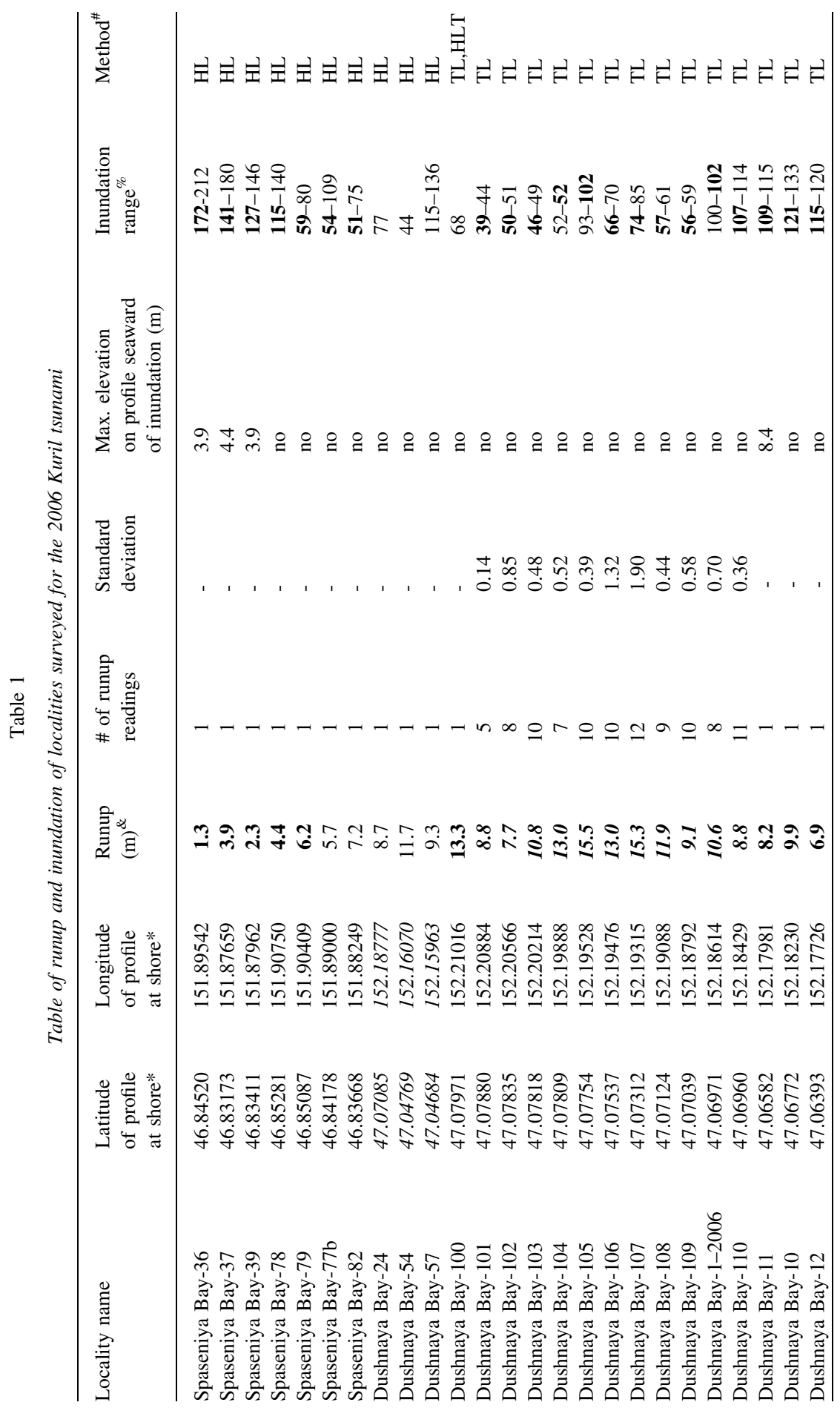




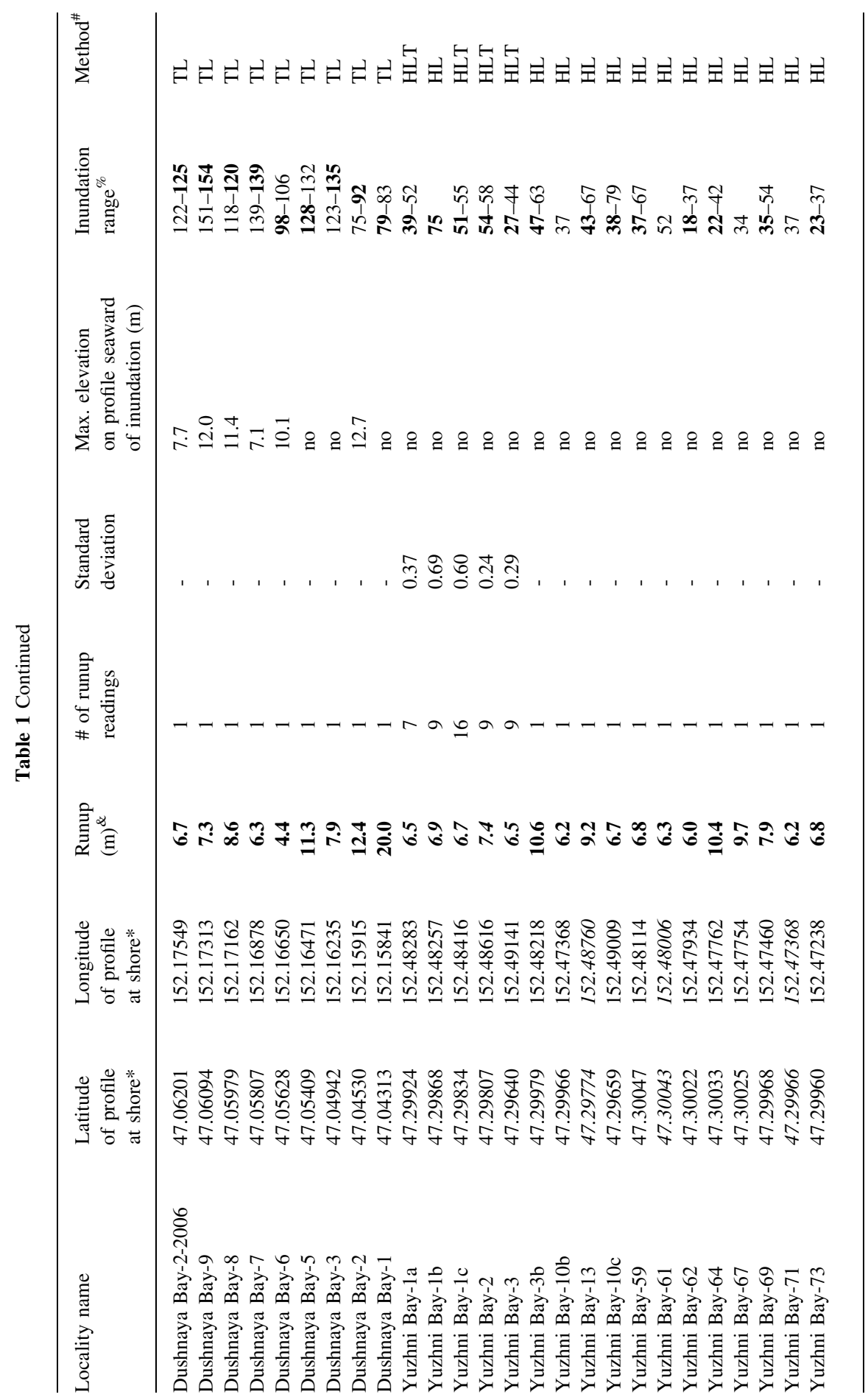




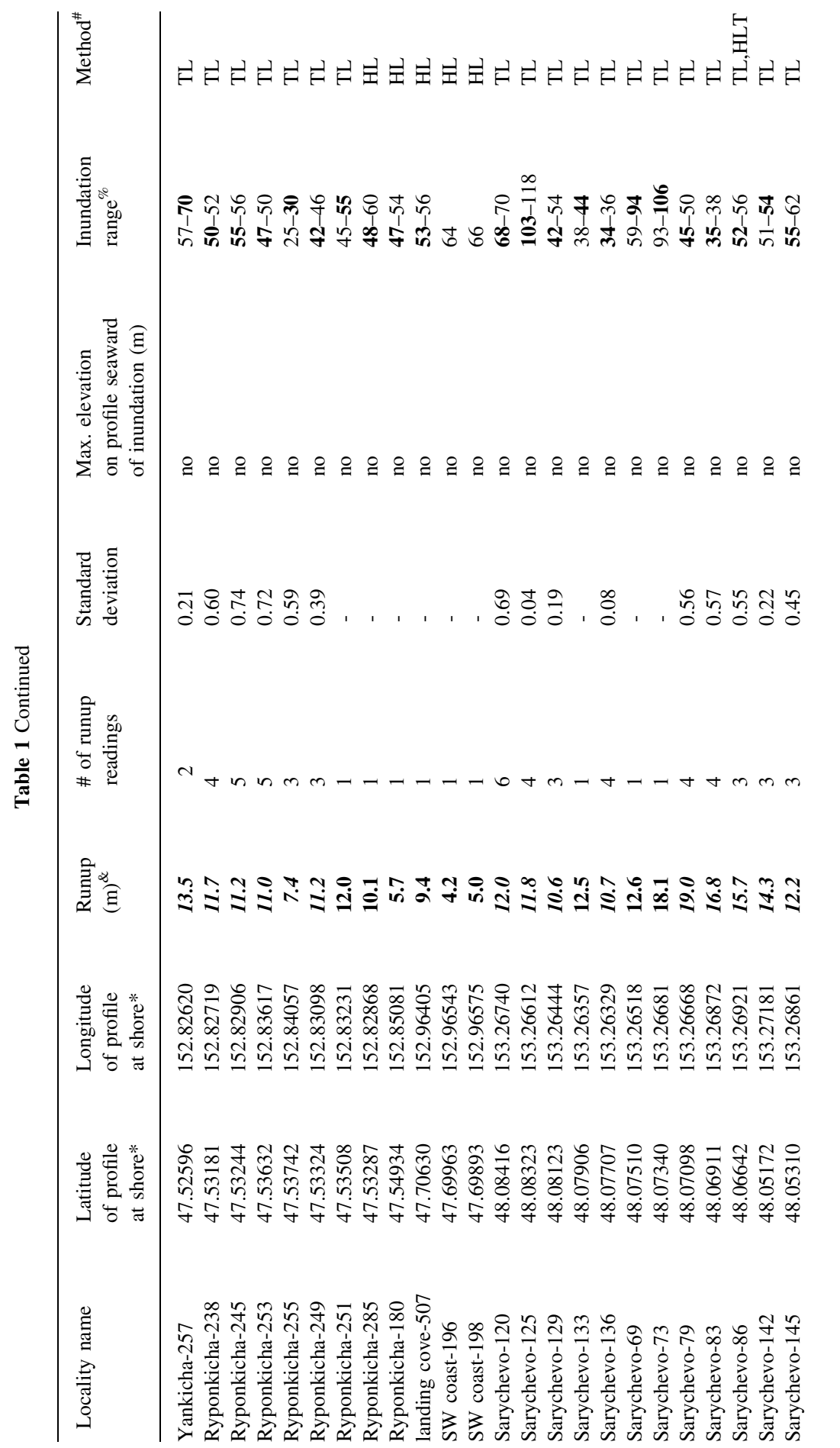




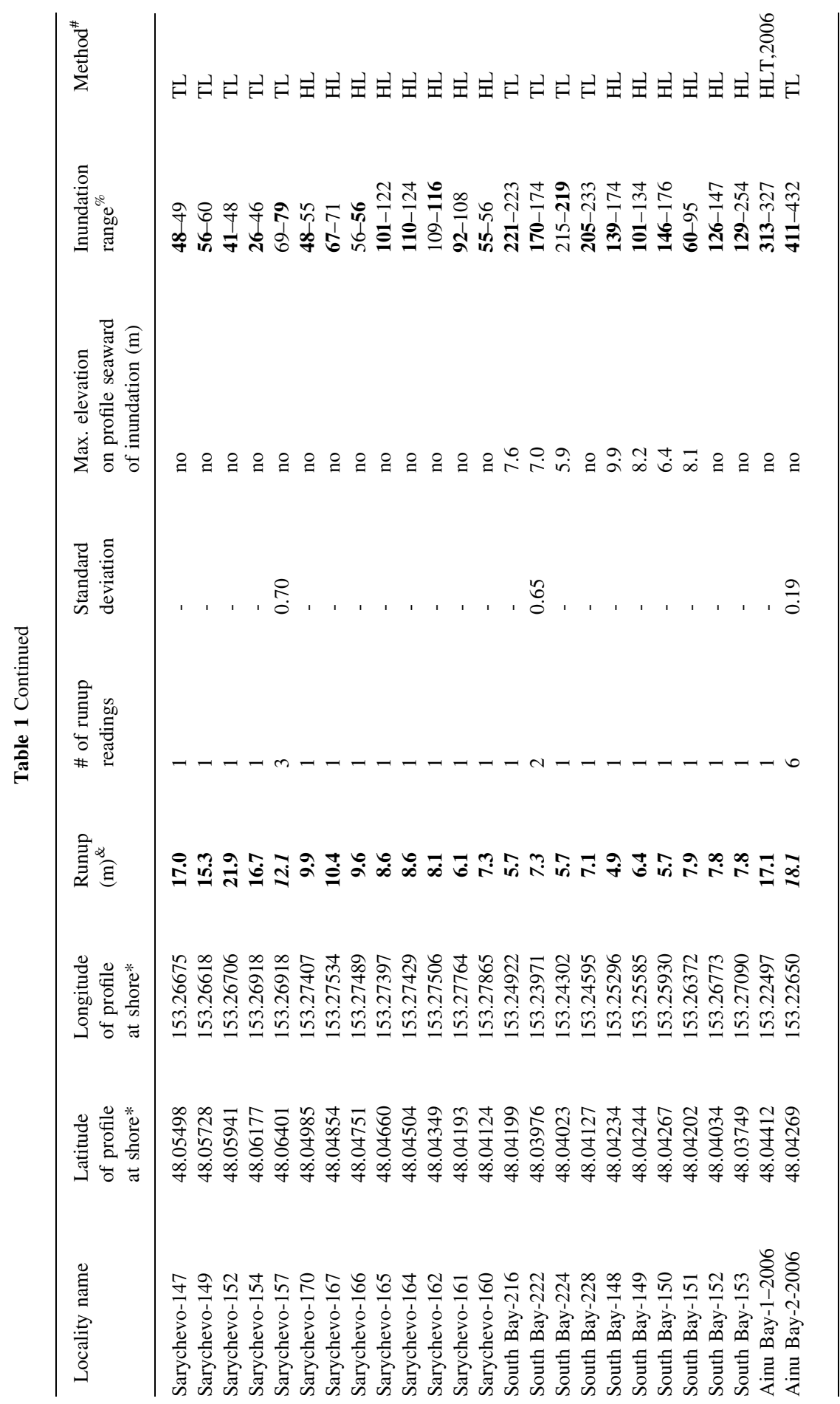




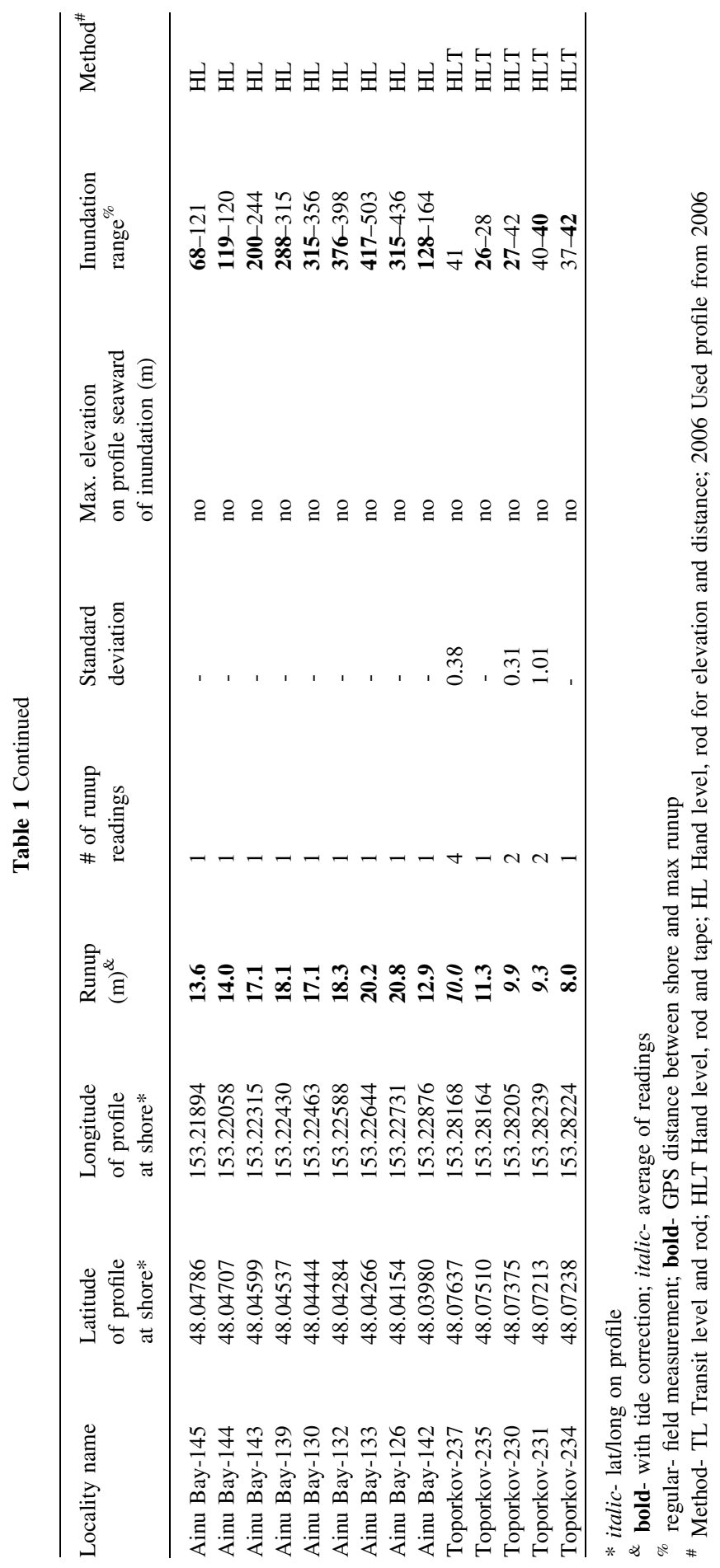


Table 2

Average runup and inundation for each bay surveyed, differentiated by coastal geomorphology

\begin{tabular}{|c|c|c|c|c|}
\hline Island & Locality name & Coastline type & $\begin{array}{l}\text { Average } \\
\text { runup }(\mathrm{m})\end{array}$ & $\begin{array}{l}\text { Average } \\
\text { inundation (m) }\end{array}$ \\
\hline Simushir & Spaseniya Bay & coastal plain & 4.86 & 111 \\
\hline Simushir & Dushnaya Bay & coastal plain & 8.08 & 121 \\
\hline Simushir & Dushnaya Bay & short, steep & 12.56 & 65 \\
\hline Ketoi & Yuzhni Bay & short, steep & 7.50 & 39 \\
\hline Ushishir & Yankicha, Ryponkicha & short, steep & 10.43 & 49 \\
\hline Rasshua & SW coast & short, steep & 6.21 & 61 \\
\hline Matua & Sarychevo & coastal plain & 9.23 & 108 \\
\hline Matua & Sarychevo & short, steep & 13.36 & 57 \\
\hline Matua & South Bay & coastal plain & 6.64 & 152 \\
\hline Matua & Ainu Bay & coastal plain & 17.02 & 268 \\
\hline Matua & Toporkov & short, steep & 9.84 & 35 \\
\hline
\end{tabular}

locations with records, the 2007 tsunami was five times smaller than 2006 at YuzhnoKurilsk ( $\sim 550 \mathrm{~km}$ to the south of our field area), and less than half as high at Malokurilsk ( $\sim 500 \mathrm{~km}$ to the south of our field area) (refer to RABINOVICH et al., 2008 for tide gage records). Furthermore, the $\mathrm{M}_{\mathrm{w}}$ 8.1-8.3 1994 Shikotan tsunami-comparable in earthquake mechanism to 2007 and with a larger tsunami at most trans-Pacific sitestypically produced $3-8 \mathrm{~m}(\max 10 \mathrm{~m})$ runup in the Habomai island group, east of Kunashir Island, close to the trench, and $1-4 \mathrm{~m}(\max 6 \mathrm{~m})$ in the southern Kurils themselves (Yen et al., 1995; KaISTREnKo, 1997; NGDC database). Average runup at sites parallel to the 1994 source is less than $5 \mathrm{~m}$, whereas the average runup we surveyed parallel to the 2006 and 2007 ruptures (see below) is about $10 \mathrm{~m}$.

In addition to arguments based on measured tsunami height and runup, we argue that the effects we surveyed were primarily from 2006 because local conditions on the islands were different for the two tsunamis. A Landsat image of Dushnaya Bay from 22 November 2006 shows extensive regions without snow at lower elevations. However, weather records from December 2006 and early January 2007 in Severo-Kurilsk and YuzhnoKurilsk (to the north and south of the field area) indicate that there would have been snow accumulation on the islands before the 2007 tsunami. Thus a frozen, snow-covered coast in January would be less susceptible to erosion and subsequent deposition, including movement of the beach debris we used to indicate runup. Tsunamis do not necessarily erode snow (particularly if ice-covered snow) during inundation (MinOuRA et al., 1996).

In Dushnaya Bay on Simushir Island, there was evidence along many profiles for a smaller wave postdating the largest wave to come ashore-we cannot confidently attribute this evidence to a later wave of 2006 or to 2007. For example, we observed a thin wrack line from a smaller wave ( $\sim 3-5 \mathrm{~m}$ elevation). Also, we observed complex tsunami deposits on several profiles, where a patchy sand deposit (average maximum elevation $5 \mathrm{~m}$ ) lay above a layer of flattened vegetation, which, in turn, covered a 


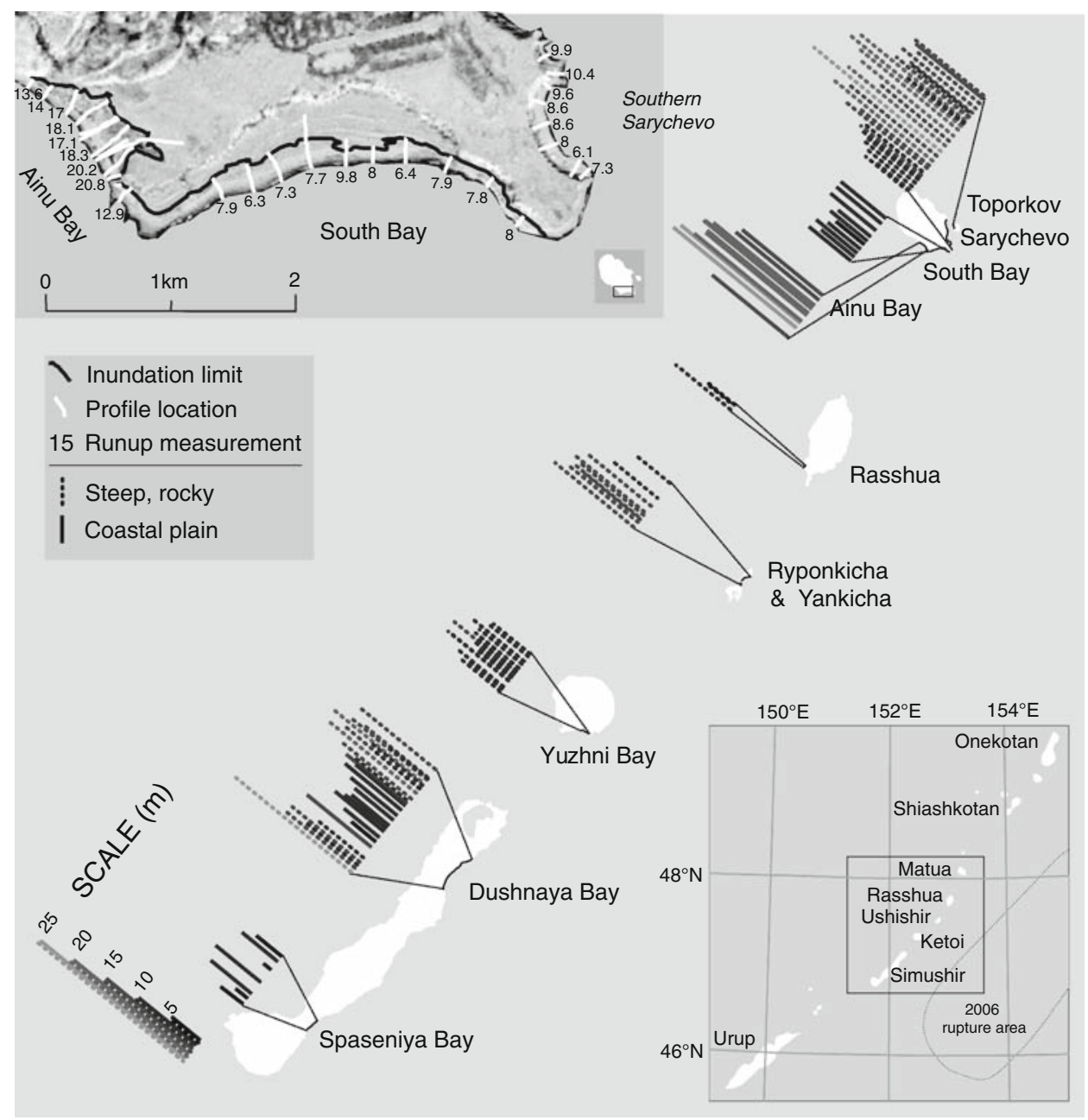

Figure 4

Summary of maximum runup of the 15 November 2006 tsunami, by location, for 130 field measurements. Values are categorized by the regional coastal geomorphology (refer to Fig. 3). Inset upper left: Detailed map of inundation and runup for southern Matua Island. Inset lower right: Location of the survey area.

continuous, coherent deposit. Such a depositional sandwich is what we expect from a second tsunami wave inundating over snow (Fig. 5), in which case these deposits would be from a smaller, 2007 tsunami.

\section{Runup Observations and Inundation}

Measured runup in the middle Kuril Islands (Simushir to Matua, about $200 \mathrm{~km}$ along strike) from the 2006 tsunami was typically 5-15 m, with a range of 2-22 m (Tables 1 


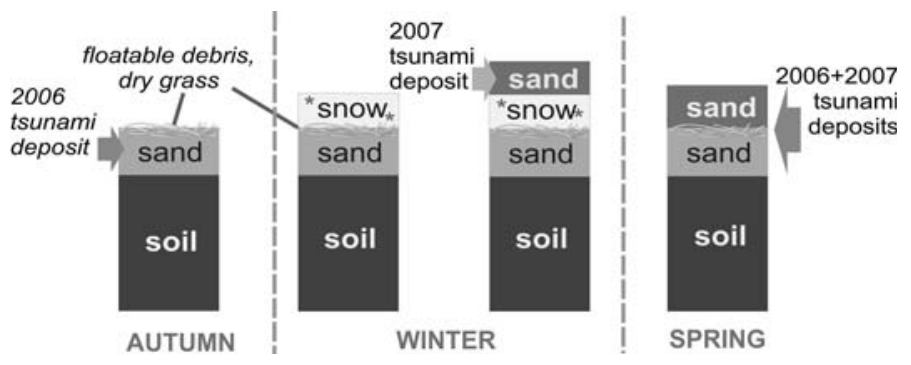

Figure 5

Schematic diagram of how the stratigraphic relationship of the 15 November 2006 and 13 January 2007 tsunami deposits appeared in the field. Snow that fell after the first tsunami would bury the 2006 deposit, floatable debris, and any vegetation still standing. The snow is not necessarily eroded in all locations by the second tsunami, and the resulting complex deposit has a thin layer of debris and vegetation in the middle.

and 2, Fig. 4), and a raw average of $10.2 \mathrm{~m}$. Measured inundation varied from 20 to $500 \mathrm{~m}$, with a raw average of $95 \mathrm{~m}$. Average runup gives the tsunami a 3.85 on the $\mathrm{S}$. Soloviev Tsunami Intensity scale (Soloviev, 1972), the standard intensity scale used in the NGDC and NTL global tsunami databases:

$$
I=1 / 2+\log _{2} H_{a v}
$$

where $H_{a v}$ is the average height of the tsunami on the nearest coast. This scale does not take into account the distance along the shoreline of the surveyed region.

On some profiles (e.g., Central Dushnaya Bay profile in Fig. 3), seaward of maximum inundation, the tsunami over-topped beach ridges or sand dunes that were higher elevation than runup, which is by definition, elevation at maximum inundation. For these cases, Table 1 provides both runup and also maximum elevation along the profile, seaward of (maximum) inundation. Elevations along the profile do not take into account tsunami water depth, consequently the water height would have been even higher. We include the intra-profile data, in addition to runup and inundation, because they facilitate representation of the magnitude and behavior of the tsunami wave.

Variability in runup and inundation of the 2006 middle Kurils tsunami was in large part due to coastal geomorphology. Naturally, our longer inundation values are from lower, flatter coastal plains, and higher runup values generally from steep, protruding headlands (Table 2). In many of the cases we studied, the steep slope or cliff backing the coastal plain limited tsunami penetration. When a tsunami hits a reflector, such as a sea cliff, the energy not reflected back to the sea will be converted into vertical runup, increasing its height (BRiggs et al., 1996; Pelinovsky et al., 1999). Tsunami modeling will enable us to determine the degree to which coastal geomorphology, as well as bathymetry, affected tsunami runup; that work is in progress. 


\section{Tsunami Sediment Transport and Deposition}

All affected shorelines showed evidence of erosion and deposition, and we made systematic measurements on many profiles (Table 3). Where loose sediment was available on the beach or in the nearshore, we observed deposits of sand, gravel, and cobbles on the coastal plain surface, burying turf and dead vegetation (Figs. 6B and D). Most deposits resemble sediment of the beach; more detailed analyses are forthcoming. In addition to beach sand and gravel, sediment also was derived from eroded scarps, from plucked turf and cobbles, and from artificial structures. Where the beach was composed of sediment larger than cobbles, no coherent, continuous deposit was present, although scattered boulders moved by the tsunami were common (see below). Where solid rock outcrop existed on the shore (observed on Ketoi and Matua), this rock was not noticeably affected by the tsunami.

We observed continuous tsunami sand sheets (e.g., Fig. 6D) in areas with sandy beaches, which also coincide with most low-relief profiles. As has been repeatedly seen elsewhere (c.f. SHi et al., 1995; Gelfenbaum and JAFFe, 2003; Bourgeois, 2009), the 2006 Kurils tsunami deposits in these cases were typically thin $(<5 \mathrm{~cm})$, thinning and fining landward. Over the 11 profiles where we made detailed observations, deposits were typically a few centimeters or less in thickness. Local variability in deposit thickness reflected previous topography; for example, a 0.5 -cm-thick deposit locally thickened to $2-5 \mathrm{~cm}$ in a rodent burrow. In general, only close to the shore or in these locally low pockets did deposits exceed $5 \mathrm{~cm}$ in thickness.

Total volumes (average sediment thicknesses summed over distance) of sediment deposited ranged from 0.4 to $6.3 \mathrm{~m}^{3} /$ unit width (Table 3 ). The deposits used in these calculations were all on vegetated surfaces, with no evidence for subsequent erosion. Sediment volume is influenced by the amount of available sediment and by topographic variations controlling the velocity of the flow (GELFEnBAum and JAFFe, 2003). Profiles with less volume of sediment deposited had narrower and rockier beaches and lower runup. The largest volumes of sediment deposition came from profiles with severe beach erosion (see next section) and higher runup.

Sediment transport was not limited to sand- to cobble-sized material-across the middle Kurils, we found evidence of tsunami transport of boulders, ranging from 10's of $\mathrm{cm}$ to $3 \mathrm{~m}$ in diameter (Table 3). Moved boulders, known as tsunami ishi (KATO and KIMURA, 1983), were sourced from the nearshore, beach, coastal plain, and artificial structures (Fig. 6C). We easily identified tsunami ishi from the nearshore by recently deceased sea life on the boulders, such as attached seaweed, encrusted bryozoan communities, and kelp holdfasts. Ishi derived from artificial structures could generally be traced back to the dam or pier or other military structures from which they were derived. We commonly identified the source location of boulders from within the vegetated beach plain by the holes left behind (see the tsunami erosion section below for further discussion). Other than typically being clean and rounded, tsunami ishi that originated on the beach are associated with no identifiable characteristics so we only assume that if other 


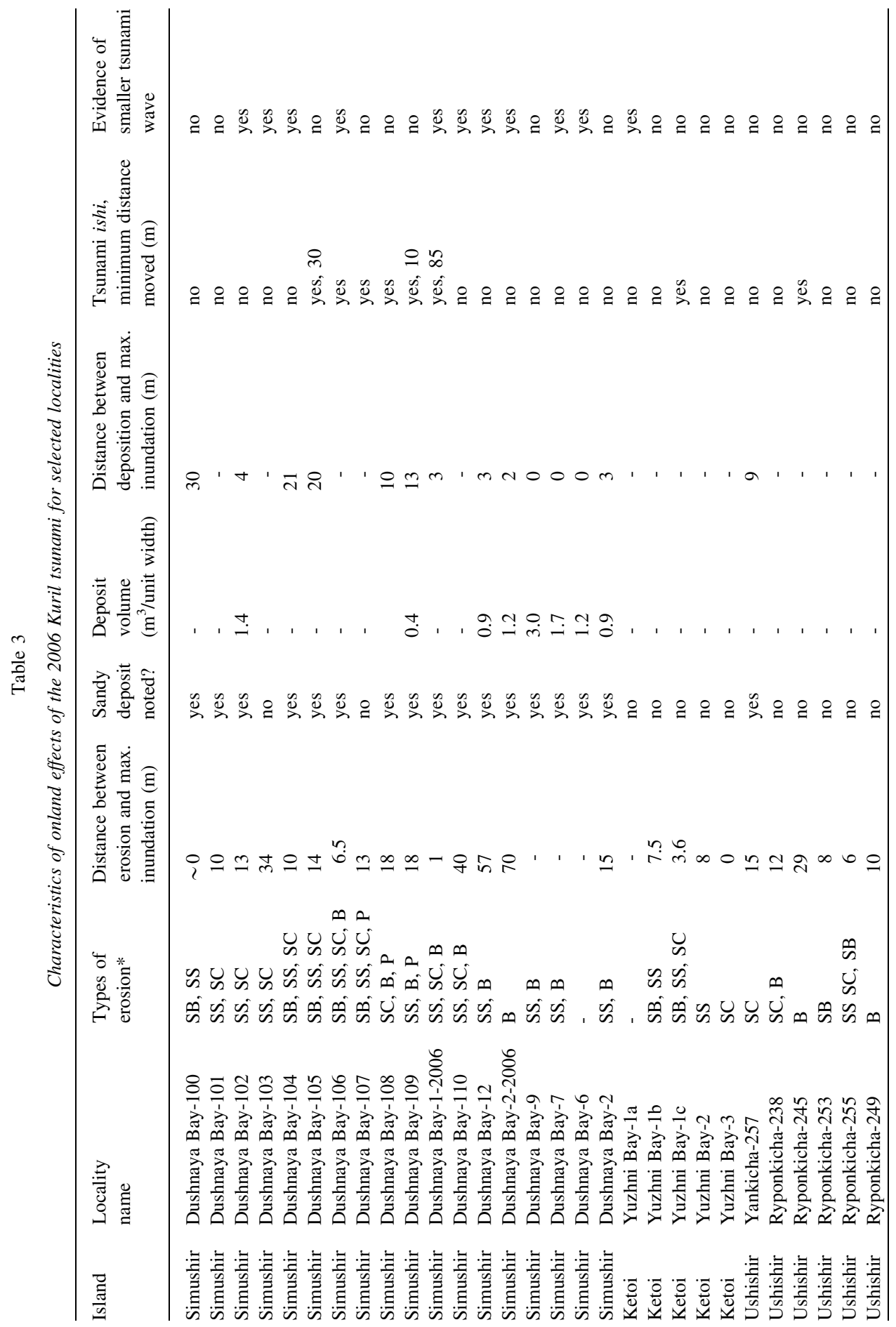


Field Survey of the 2006 Kuril Tsunami

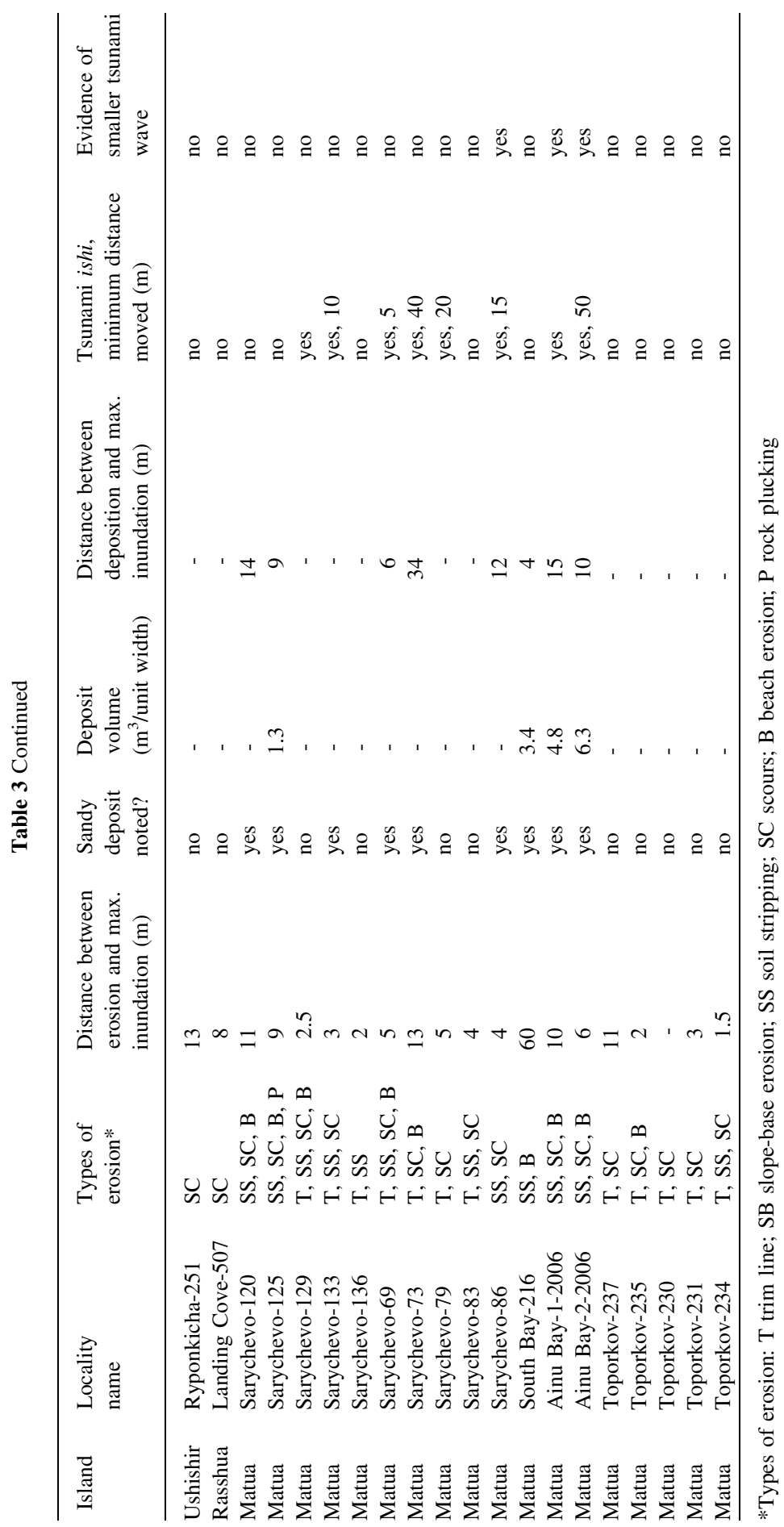



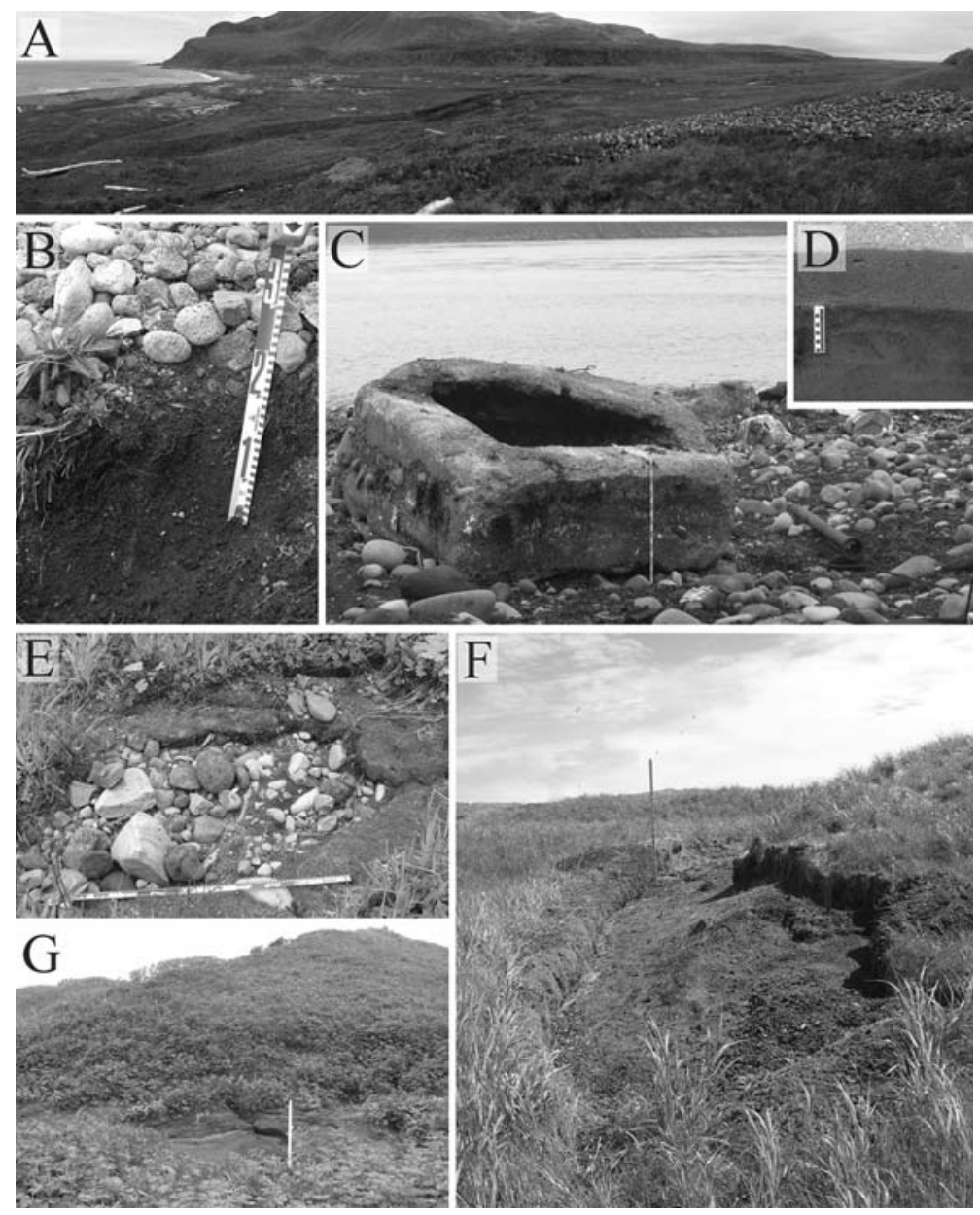

Figure 6

Deposition and erosion from the 15 November 2006 tsunami as observed in the middle Kurils. A: Ainu Bay, Matua, which experienced the maximum amount of inundation we observed (400-500 m). White flecks in the distance are large logs moved by the tsunami. B: A deposit of pebbles on top of soil and turf in Dushnaya Bay, Simushir (near profile 105). New vegetation is beginning to grow through. Measuring tape is $30 \mathrm{~cm}$. C: A tsunami $i s h i$, which was once an artificial structure offshore, with kelp holdfasts and bryozoan communities still attached. Measuring tape is $1 \mathrm{~m}$. Sarychevo coast of Matua, profile 83. D: Continuous sand sheet from Ainu Bay, Matua, Profile 2. Here, the deposit is the thickest observed anywhere (at $20 \mathrm{~cm}$ thick) and is filling a drained lake bed. E: A scour pit in Dushnaya Bay, Simushir, Profile 106. Direction of flow was from right to left. Measuring tape is $1 \mathrm{~m}$. F: Soil stripping in Ainu Bay, Matua, Profile 2. Turf and soil are still attached, but flipped over on the left (landward). The rod is $2 \mathrm{~m}$ high. G: Slope-base erosion in Dushnaya Bay, Simushir, Profile 107. The rod is $2 \mathrm{~m}$ high.

equivalent-sized boulders moved, the ones on the beach could have been moved. We recorded some tsunami ishi to have been transported at least $>85 \mathrm{~m}$ (Table 3), however we did not have time to conduct an exhaustive survey of all boulders transported. 


\section{Tsunami Erosion}

Geomorphic effects of the 2006 tsunami on the landscape varied from almost unnoticeable to devastating; two of our short-term camps from the summer field season of 2006 would have been obliterated. In general, erosion is produced by local temporal or spatial increases in boundary shear stress and clearly can also be affected by bed characteristics such as grain size and cohesion. KonNo et al. (1961) identified three types of tsunami flow over land where erosion may occur: sheet flow, linear (or concentrated, channelized) flow, and eddy flow. Holding other factors constant (such as soil cohesion, vegetation type, etc.), sheet flow results in uniform erosion, concentrated flow in spatially variable erosion, and eddies in small-scale features. The different forms of tsunami flow are generated by topography (as in UMITSU et al., 2007). Evidence is widespread for erosion from all three types of flow in the 2006 tsunami case in the middle Kuril Islands.

Far and away the two most common cases of erosion in our survey are what we call scouring and soil stripping. Documentation of scours and stripped areas are also common in tsunami literature (e.g., Gelfenbaum and JAFFe, 2003; Goff et al., 2006; KuRIAN et al., 2006; OKAL et al., 2006), and such erosional features are typically associated with sudden changes in topography or in soil characteristics. The literature most often addresses scour associated with man-made features, such as roads, buildings, bridge pylons, etc. (e.g., GoFf et al., 2006; MAHESHWARI et al., 2006; MaLiK et al., 2006). Individual scour depressions generally form from either linear or eddy flow, but the largest scours (e.g., Fig. 7C) suggest erosional sheet flow (KonNo et al., 1961). The upstream steep wall in a scour (and downstream sediment berm) form from eddies within the scour on the upstream side of the direction of flow (as in KonNo et al., 1961; Alonso et al., 2002).

Visually, we identified scours in our survey by localized pits or eroded strips of coastline with a steeper wall at one end (Figs. 6E and 7C). We define a "scour" as a localized depression generated by erosion, where vegetation and topsoil are removed entirely. Scours varied in size from less than a meter in diameter, to 100's of meters long by 10's of meters wide, and had scour depths of centimeters to meters. Scours occurred in both natural and artificial landforms; those in natural settings often had sediment accumulated in the downstream end of the depression (Fig. 6E).

We identified soil stripping by removed vegetation and generally called an area stripped rather than scoured if there was not a distinct depression. In these cases, soil or sediment removal is uniform in depth and does not significantly extend below the turf zone, or in some cases, below a cinder layer near the surface (Fig. 6F). Due to its uniformity, soil stripping suggests sheet flow (c.f. KonNo et al., 1961) without the development of strong eddies. Commonly in our field area, the tsunami exploited shallow networks of rodent burrows or WWII military trenches to initiate erosion and strip or "flay" the surface. In some locations, one edge of eroded turf was still attached and the upper soil layers were flipped over in the direction of flow (Fig. 6F). 

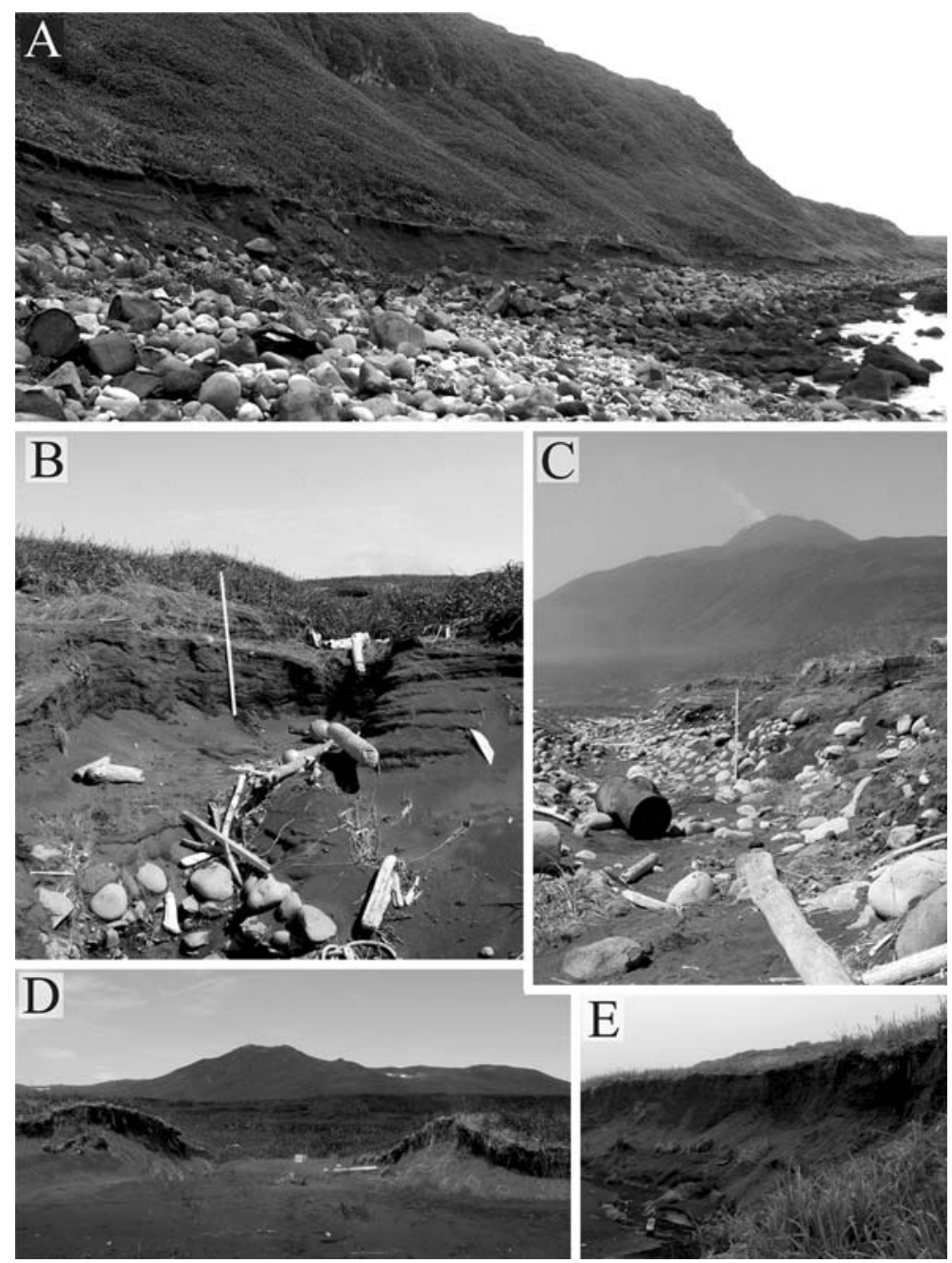

Figure 7

Examples of kinds of erosion from the 15 November 2006 tsunami as observed in the middle Kurils. A: Trim line on Matua, Sarychevo coast. B: Gullying from outflow, Ainu Bay, Matua, Profile 2. Rod is $2 \mathrm{~m}$ high. C: Large-scale scour that extends $>100 \mathrm{~m}$ laterally, in Ainu Bay, Matua, Profile 1. Rod is $2 \mathrm{~m}$ high. D: Breach through the first beach ridge in central Dushnaya Bay, Simushir, near Profile TKP10. Shovel in center of photo is $\sim 1.5 \mathrm{~m}$ high. E: En masse erosion of a stream channel wall in Dushnaya Bay, Simushir, near Profile TKP12. Bank height is $\sim 4 \mathrm{~m}$, and the cliff was eroded back $\sim 3 \mathrm{~m}$ between 2006 and 2007.

The prevalent styles of erosion on middle Kurils coastlines with a narrow beach plain, where the tsunami ran up a steep slope, were trim lines and slope-base erosion. A trim line is where soil and vegetation are removed up to an approximately uniform elevation on a slope. In contrast, we define slope-base erosion as more isolated patches than trim 
lines and only extending a meter or two above the change in slope. Trim lines (Fig. 7A) are visually striking and observable from a distance, and the uniformity of a trim line suggests sheet flow (c.f. KonNo et al., 1961). In our survey, maximum runup and inundation were in close proximity to the location of the trim line (Table 3 ); the tsunami typically continued only a meter or two above and a few meters beyond the trim line. Slope-base erosion (Fig. 6G) is not as closely tied to maximum runup as trim lines are. This kind of erosion was clearly associated with sharp slope change and may have occurred during both inflow and outflow. Because slope-base erosion is selective, it suggests linear (channelized) flow, or eddy flow associated with the sharp change in slope.

Other styles of erosion we observed, plucking of rocks embedded in soil, cliff retreat of sandy back-beach edges or stream channel walls (Fig. 7E), and breaches in beach ridges (Fig. 7D), were strongly dependent on location variables. Rocks as large as $30 \mathrm{~cm}$ in diameter were pulled out of soil leaving distinct, coherent holes in the surface. We traced some rocks a few meters to their source hole in both the seaward and landward direction, but the tsunami also removed some boulders and cobbles entirely from land, presumably transporting them offshore. We only observed plucking in locations where the tsunami had no other source of sediment and was likely sediment starved.

Cliff retreat occurred in two forms, either en masse, or as scallops or gullies. En masse, or uniform, tsunami erosion has been previously reported along the beach edge (e.g., Kurian et al., 2006; Maramai and TinTi, 2007) and along a few stream channels (MARAmai and TinTI, 2007). It is more likely to occur during inflow, when topographic effects are less important (e.g., UMITsu et al., 2007). In our surveys, we identified en masse cliff retreat by evidence that an extended stretch of coastline eroded landward in a fairly uniform way. For example, compared to our 2006 observations, in 2007 most backbeach scarps or stream channel walls (e.g., Fig. 7E) exposed to the ocean appeared more straight and regular. We observed or measured up to $>50 \mathrm{~m}$ of en masse erosion, the largest amount occurring in Ainu Bay, Matua (MAcInNes et al., 2007).

Irregular scallops and gullies generally represent zones of concentrated outflow as they are produced primarily in locations where troughs intersect stream channels, or where a section of beach plain is lower then its immediate neighbors (e.g., UMITSU et al., 2007). Gelfenbaum and JafFe (2003) and Umitsu et al. (2007) found that incoming tsunamis flowed nearly perpendicular to the shore, but backwash returned obliquely to the shore in local topographic lows. In our survey of 2006 tsunami effects in the middle Kurils, gullies and scallops were common, especially where there was a preexisting backbeach scarp. The tsunami dug some gullies as deep as $3 \mathrm{~m}$ into the pre-existing beach scarp; these gullies in 2007 resembled dry waterfalls (Fig. 7B). Some of these dramatic gullies were produced or enhanced where inflow over a steep beach face was then concentrated (channelized) between two beach ridges and then outflow was focused into what we presume were pre-existing lows in the seaward-most beach ridge.

Although we are confident that most of the features we documented in our survey were due to erosion from the 15 November 2006 tsunami, the unvegetated beach is a 
location of constant change, and it can be difficult to say what changes are directly related to a tsunami (or in our case, two tsunamis), especially over the course of a full year (SHEPARD et al., 1950). For this reason, we paid little attention to changes on the unvegetated portion of our profiles. Besides the back-beach cliff retreat mentioned, the only other kind of beach change we could attribute to the tsunami with any amount of confidence was localized breaching through the back-beach cliff and seaward-most beach ridge. In three locations in Dushnaya Bay, we found breaches (width on the scale of meters) through the first beach ridge, at least one of which is known to have formed between 2006 and 2007 (Fig. 7D). A few older beach ridges in our field area are also breached; we tentatively suggest these breaches are preserved geomorphic change from paleotsunamis.

Where the 2006 tsunami was large, erosion extended farther inland, and commonly the inland limit of erosion exceeded that of deposition (Table 3). A direct comparison of before and after using three topographic profiles from 2006, reoccupied in 2007, shows that the tsunami removed many times more sediment than it deposited on land. Even where erosion was at a minimum, and deposits extended almost to the limit of inundation, more sediment was eroded than can be accounted for by the tsunami deposit (c.f. MACINNES et al., 2007), and we presume this sediment was transported offshore.

Others have also documented beach-profile changes due to tsunami erosion. KuRIAN et al. (2006) measured before and after (unvegetated) beach profiles in India and found some areas that experienced erosion and others that experienced deposition, but were uncertain as to what was directly from the tsunami and what was from previous or subsequent beach processes. UMITsU et al. (2007) also noted beaches retreated or vanished following the 2004 Indian Ocean tsunami in Indonesia and Thailand, but were not able to quantify the change. Breaches by tsunami have been previously documented in Japan from the 1960 Chile event (KonNo et al., 1961) and the Maldives from the 2004 Indian Ocean event (FrITZ et al., 2006).

\section{Paleotsunami Deposits in the Affected Region - Preliminary Results}

The presence of paleotsunami deposits in the middle Kurils indicates that ruptures at least on the scale of the 2006 event are not uncommon, and support the postulate that before 15 November 2006, the region was a seismic gap. For example, in the summer of 2006, before the 15 November 2006 tsunami, we had collected evidence of tsunami deposits as high as $20 \mathrm{~m}$ above sea level in Dushnaya Bay on northern Simushir (Fig. 8, profile 2006-2) — as many as three such deposits since 400 A.D. (tentative age of a marker tephra, based on correlation with dated archaeological sites).

In both 2006 and 2007 field seasons, in order to develop chronologies and determine pre-histories of eruptions, earthquakes and tsunamis, we made numerous excavations along selected profiles, using techniques as described in BourgEOIs et al. (2006) (e.g., Fig. 9). In the subsurface we identified many sand layers we interpret to be tsunami 


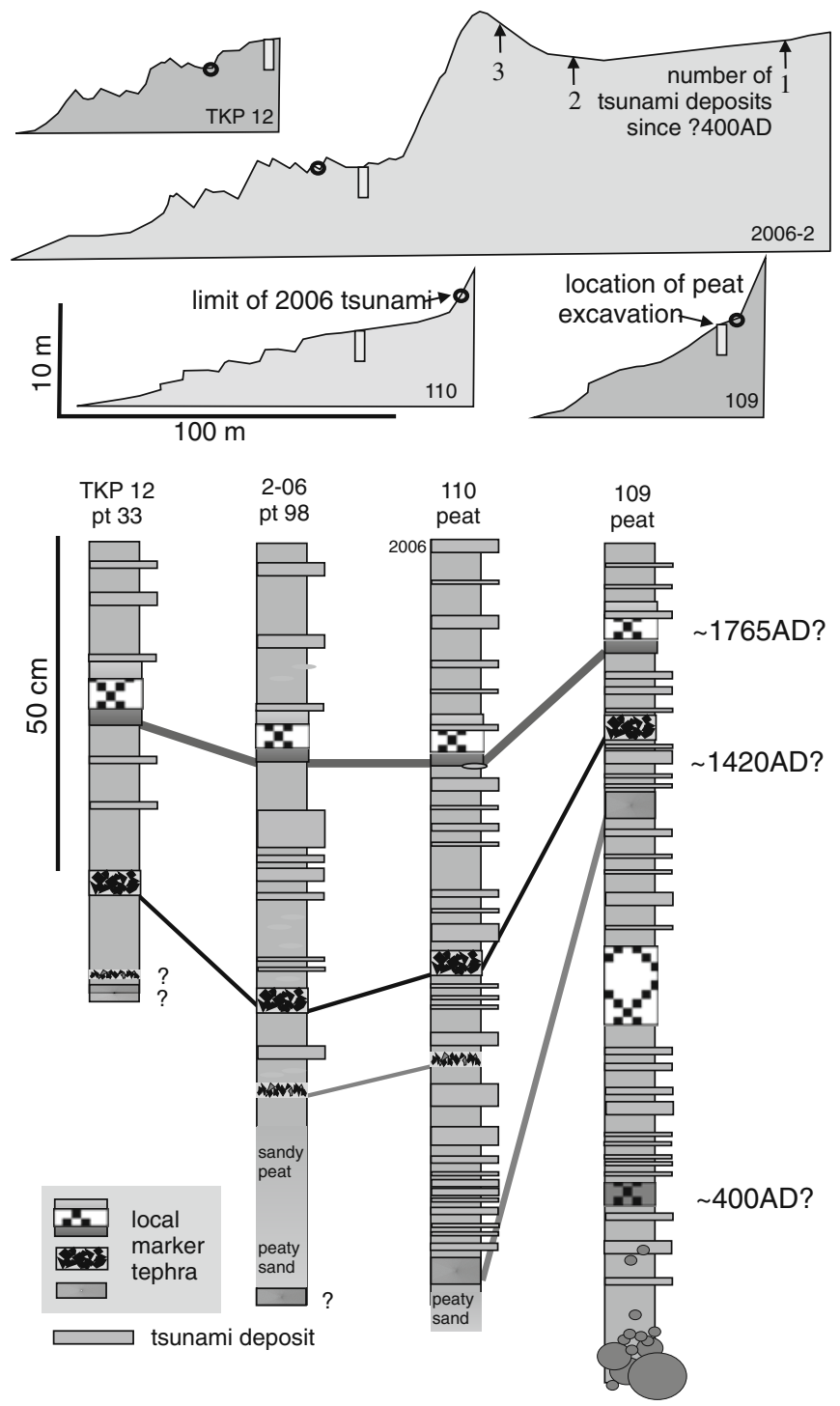

Figure 8

Paleotsunami deposits in peat sections on topographic profiles from Dushnaya Bay, Pacific Coast of northern Simushir (Fig. 2). Above: Four of 25 profiles measured in Dushnaya Bay. On each profile, the limit of the 15 November 2006 tsunami is shown by a circle, and the location of peat excavations (illustrated below) is shown by a rectangle. In addition, on profile 2006-2, the locations of three high-terrace excavations are shown with arrows, and the number of tsunami deposits present in the upper parts of those excavations indicated. Below: From a peat excavation in each profile, the logged description of tephra and tsunami deposits. The background of the sections is peat unless otherwise indicated. We show only key local marker tephra-the ones we could correlate all along the bay, in many excavations. Ages of these tephra are based on the historical record (an observed eruption c. 1765) and on radiocarbon dating of correlative archaeological sections. These dates should be taken as tentative. 
deposits, based on their sheet-like geometry, (beach) sand composition, and location above storm limits. Many of our excavations have been at sites beyond the limit of the 2006 tsunami deposit (Figs. 8 and 9), indicating locally higher paleo-runup.

Herein we report only examples of the presence (not chronology or recurrence interval) of paleotsunami deposits because our age control is still being developed. This age control is and will be based on radiocarbon dating above and below marker tephra on each island. Dates reported in Figures 8 and 9 should be considered tentative.

On northern Simushir Island (Dushnaya Bay, Fig. 2), in several peat excavations at elevations at or above the limit of the 15 November 2006 tsunami, sand layers are common in the subsurface (Fig. 8). With our tentative age control, it is fair to say that tsunamis locally as large or larger than 15 November 2006 have occurred as often as once per $\sim 100$ years. Of course, some of these tsunamis might have been more local (less regional) than 2006, or triggered by submarine or coastal landslides.

On southern Matua Island (South Bay, Fig. 2; inset Fig. 4), there is also a record of a numerous prehistoric tsunamis locally larger than 15 November 2006 (Fig. 9). Compared to Dushnaya Bay on Simushir, the record is more difficult to read because cinders from the local volcano, Sarychevo, are common and thick. For example, some of the interpreted tsunami deposits on Matua are cindery beds containing beach sand.

Some previous work has been published on Holocene paleotsunami deposits south of the middle Kurils, on Kunashir and Iturup islands, north of Hokkaido (ILIEv et al., 2005). On Kunashir, those authors found 17 thin sand layers intercalated with peat and lacustrine deposits. Field observations, grain-size composition, and diatom data were used to attribute the deposits to tsunamis; age control is based on radiocarbon dating and tephra

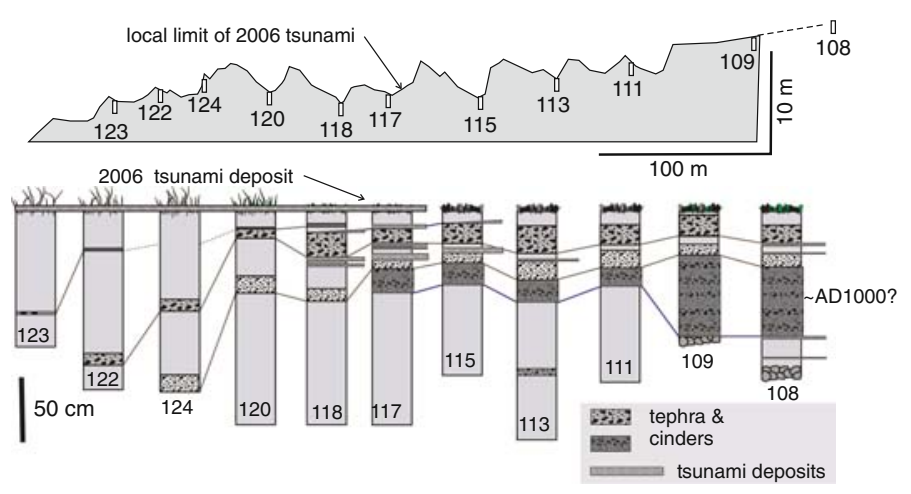

Figure 9

Profile 216, one of ten topographic profiles measured in South Bay, Matua Island (Fig. 2 and inset Fig. 4), and the logged description of excavations along that profile, simplified to include only prominent tephra. In 2006, we made ten excavations on this profile, and one nearby (108). In 2007, we mapped the 15 November 2006 tsunami deposit onto this profile, which extended just to excavation 117. Note that some paleotsunami deposits extend beyond this limit (e.g., excavations 115, 113, 108). Age control on these sections remains tentative, pending radiocarbon dates and additional work on tephra correlation. 
stratigraphy. The documented sand layers are present at elevations to $7 \mathrm{~m}$ and inland distances up to $2.5 \mathrm{~km}$. Iliev et al. (2005) reported paleotsunami deposits as old as 6,0007,000 years and attempted to correlate these deposits from Iturup to Hokkaido, with recurrence intervals for large events of about $500 \mathrm{yr}$.

\section{Summary}

The nearfield runup of the 15 November 2006 middle Kurils tsunami exceeds 10 times the height of water heights recorded on any Pacific Ocean tide gages (NGDC catalogue). Average runup in the middle Kurils was about $10 \mathrm{~m}$, with some field sites recording $>20 \mathrm{~m}$. In many locations the tsunami inundated the entire coastal plain area and reflected off cliffs backing the plain. Maximum inundation reached as far as $400 \mathrm{~m}$ and was mostly limited by topography.

Wherever fine-grained (primarily sand-sized) sediment was available on the beach or nearshore, we found continuous tsunami deposits. Areas deficient in sand still showed evidence of sediment transport, with tsunami ishi up to $3 \mathrm{~m}$ in diameter pulled up from offshore, transported within the coastal plain, or washed out to sea. The presence of paleotsunami deposits in the middle Kurils confirms that large ruptures in this section of the subduction zone are not uncommon, although the source characteristics of these paleoevents may vary. Many of the paleotsunami deposits are more extensive than deposits of the 15 November 2006 tsunami.

Erosion from the 2006 tsunami was greatest where runup exceeded $10 \mathrm{~m}$. We predict some scours and gullies will likely be permanent alterations of the geomorphology of the coastline. At sites with high runup, erosion extended almost as far as inundation. However, erosion was minimal where runup was less than $10 \mathrm{~m}$, such as in central Dushnaya Bay, Simushir; in these localities the geomorphic effect of the tsunami will be indistinguishable in the near future.

\section{Future Work}

We returned to the Kuril Islands in the summer of 2008, the final of three extended field seasons funded by the NSF Kurils Biocomplexity Project. The aims of the geology and tsunami team members for 2008 included visits to the Pacific coasts of Rasshua, Shiashkotan and Onekotan, where the 2006 tsunami left a record. We also visited northern Urup; our brief surveys in 2006 and 2007 showed that effects on southern Urup were

minimal. With a complete set of observations, we can compare our survey results with models, e.g., by M. Nosov in Levin et al. (2008) and RABinovich et al. (2008).

From the 2007 season, we have an extensive suite of samples of the 2006 tsunami deposit along eleven profiles, and we will report in more detail on their character, following grain size analysis. For Dushnaya Bay (northern Simushir) and southern Matua, 
our topographic profiles are dense enough that we will be able to generate 3-D topography. In four cases, we also have before (2006) and after (2007) profiles, and in many cases, we have quantified erosional features. Therefore, after acquiring higher resolution shallow bathymetry, we plan to model local runup and compare the geological effects to modeled tsunami behavior. We also plan for our data to present suitable benchmarks for the study of tsunami erosion and deposition (c.f. Huntington et al., 2007).

As noted above, our ongoing work on paleotsunamis in the Kurils requires more radiocarbon dating, and more study of tephra chronology and correlation. Such work is a challenge because of the wide spacing of the islands, and the number of active volcanoes. However, our preliminary work is promising, and quantification of paleotsunami frequency (and possibly size) throughout the Kurils is one of our intermediate-term goals.

\section{Acknowledgements}

We are very grateful for the helpful reviews of Alexander Rabinovich, Alexei Ivashchenko and Kenji Satake. Funding for fieldwork was provided primarily by the Kuril Biocomplexity Project (NSF grant \#0508109, PI Ben Fitzhugh; http://depts.washington.edu/ikip/index.shtml) and also by the Institute of Marine Geology and Geophyics, Yuzhno-Sakhalinsk, Russia (Director Boris Levin). The following people helped us collect field data in the middle Kurils: Kirill Ganzey, Sergei Chirkov, Andrei Kharlamov, Misty Nikula, Ben Fitzhugh, Boris Levin, Mikhail Nosov and Elena Sassorova.

\section{REFERENCES}

Alonso, C.V., Bennet, S.J., and Stein, O.R. (2002), Predicting head cut erosion and migration in concentrated flows typical of upland areas, Water Resources Research 38(12), 1303, doi:10.1029/2001WR001173.

Ammon, C.J., KANAMORI, H., and LAY, T. (2008), A great earthquake doublet and seismic stress transfer cycle in the central Kuril Islands, Nature 451, 561-565.

Apel, E.V., Burgmann, R., Steblov, G., Vasilenko, N., King, R., and Prytkov, A. (2006), Independent active microplate tectonics of northeast Asia from GPS velocities and block modeling, Geophys. Res. Lett. 33, L11303, doi:10.1029/2006GL026077.

Bourgeols, J. (2009), Geologic effects and records of tsunamis. In The Sea: Volume 15, Tsunamis (eds. Bernard, E.N. and Robinson, A.R.), Harvard University Press, 55-91.

Bourgeois, J., Pinegina, T.K., Ponomareva, V., and Zaretskaia, N. (2006), Holocene tsunamis in the southwestern Bering Sea, Russian Far East, and their tectonic implications, Geol. Soc. Am. Bull. 118(3/4), 449-463.

Briggs, M.J., Synolakis, C.E., Kanoglu, U., and Creen, D.R. (1996), Runup of solitary waves on a vertical wall, in Long-Wave Runup Models. In Proc. Internat. Symp., Friday Harbor, USA, 12-17 September 1995 (eds. H. Yeh, P. Liu, C. Synolakis), World Science, pp. 375-383.

Cook, D.B., FujtTA, K., and McMullen, C.A. (1986), Present-day plate interactions in northeast Asia - NorthAmerican, Eurasian, and Okhotsk plates, J. Geodyn. 6, 33-51.

DeMets, C., Gordon, R.G., Argus, D.F., and Stein, S. (1990), Current plate motions, Geophys. J. Int. 101, $425-478$. Farreras, S.F. (2000), Post-tsunami field survey procedures: An outline, Natural Hazards 21, 207-214.

Fedotov, S.A. (1965), Regularities of the distribution of large earthquakes of Kamchatka, the Kuril Islands and north-eastern Japan, Akad. Nauk SSSR Inst. Fiziki Zemli Trudy 36 (203), 66-93. (in Russian). 
Fritz, H.M., Synolakis, C.E., and McAdoo, B.G. (2006), Maldives field survey after the December 2004 Indian Ocean tsunami, Earthquake Spectra 22(S3), S137-S154.

FuJII, Y., and SATAKE, K. (2008), Tsunami sources of November 2006 and January 2007 great Kuril earthquakes, Bull. Seismol. Soc. Am. 98(3), doi: 10.1785/0120070221.

Gelfenbaum, G. and JAFFe, B. (2003), Erosion and sedimentation from the 17 July 1998 Papua New Guinea tsunami, Pure. Appl. Geophys. 160, 1969-1999.

Goff, J., Liu, P.L.-F., Higman B., Morton R., Jaffe B.E., Fernando H., Lynett, P., Fritz, H., Synolakis C., and Fernando S. (2006), Sri Lanka field survey after the December 2004 Indian Ocean tsunami, Earthquake Spectra 22(S3), S155-S172

Gorshrov, G.S., Volcanism and the Upper Mantle; Investigations in the Kurile Island Arc (New York, : Plenum Publishing Corp. 1970), 385 pp.

HARADA, T. and IsHIBASHI, K. (2007), Two parallel trench-normal fault planes within the Pacific slab associated with the 1994 and 2000 Kurile earthquakes as revelated by simultaneous relocation of their main shocks and aftershocks, Earth Planets Space 59, e25-e28.

Huntington, K., Bourgeois, J., Gelfenbaum, G., Lynett, P., Jaffe, B., Yeh, H., and Weiss, R. (2007), Sandy signs of a tsunami's onshore depth and speed, Eos, Transactions, AGU 88(52), 577-578.

JI, C. (2006), Rupture process of the 2006 Nov. 15 Magnitude 8.3- Kuril Island earthquake, http:// earthquake.usgs.gov/eqcenter/eqinthenews/2006/usvcam/finite_fault.php (last accessed May 2008).

Ji, C. (2007), Rupture process of the 2007 Jan. 13 Magnitude 8.1 - Kuril Island earthquake (revised), http:// earthquake.usgs.gov/eqcenter/eqinthenews/2007/us2007xmae/finite_fault.php (last accessed May 2008)

Iliev, A.Y., Kaistrenko, V.M., Gretskaya, E.V., Tikhonchuk, E.A., Razigaeva N.G., Grebennikova, T.A., GanZey, L.A. and Kharlamov, A.A., Holocene tsunami traces on Kunashir Island, Kurile Subduction Zone. In Tsunamis: Case Studies and Recent Developments (ed. SATAKe, K.), Advances in Natural and Technological Hazards Research (Springer, Netherlands 2005) 23, 171-192.

Kaistrenko, V.M., ed. (1997), Concrete tsunami manifestation: Tsunamis of 1993 and 1994 on the Russian coast, Geodynamics of Tectonosphere of the Pacific Eurasia Conjunction Zone, Vol. VII, Yuzhno-Sakhalinsk, 193 pp. (in Russian).

Kato, Y. and Kimura, M. (1983), Age and origin of so-called "Tsunami-ishi”, Ishigaki Island, Okinawa Prefecture, J. Geol. Soc. Japan 89, 471-474.

Kelly, A. (2006), Recent tsunami highlights need for awareness of tsunami duration, Eos, Transactions, AGU $87,566-567$.

Konno, E., Imai, J., Tkayanagi, Y., Nakagawa, H., Onuki, Y., Shiata, T., Mit, H., Kitamura, S., Kodaka, T., and KataокA, J. (1961), Geological survey on the Chile Earthquake Tsunami affected areas in the Sanriku coast, northeast Japan, Contrib. Inst. Geol. Palaeontol. Tohoku Univ. 52, 1-40 (in Japanese with English abstract).

Kurian, N. P., Pillai, A.P., Rajith, K., Murali Krishnan, B. T. and Kalaiarasan, P. (2006), Inundation characteristics and geomorphological impacts of December 2004 tsunami on Kerala coast, Current Science 90(2), 240-249.

Kuzin, I.P., Lobkovsky, L.I., and Solov'eva, O.N. (2001), Characteristics of seismicity in the central Kurile region, Izvestiya - Russian Academy of Sciences, Physics of the Solid Earth 37(6), 464-473.

Laverov, N.P., Lappo, S.S., Lobkovsky, L.I., Baranov, B.V., Kulinich, R.G., and Karp, B.Y. (2006), The central Kuril "gap": Structure and seismic potential, Doklady Earth Sciences 409, 787-790.

Levin, B.V., Kaistrenko, B.M., Rybin, A.B., Nosov, M.A., Pinegina, T.K., Razhigaeva, N.G., Sassorova, E.V., Ganzei, K.S., Ivelskaya, T.N., Kravchenovskaya, E.A., Kolesov, C.V., Evdokimov, Y.V., Bourgeois, J., MacInNes, B., and Fitzhugh, B. (2008), Manifestations of the tsunami on November 15, 2006, on the Central Kuril Islands and results of the runup heights modeling, Transactions (Doklady) of the Russian Academy of Sciences, Earth Science Section 419 (2), 335-338.

Macinnes, B.T., Bourgeois J., Pinegina, T.K., Martin, M. E., and Kravchenovskaya, E.A. (2007), Tsunami erosion: Geomorphology before and after the 15 Nov. 2006 tsunami in the Middle Kuril Islands, Russia, Eos Trans. AGU 88(52), Fall Meet. Suppl., Abstract OS31A-0158.

Maheshwari, B.K., Sharma, M.L., and Narayan, J.P. (2006), Geotechnical and structural damage in Tamil Nadu, India, from the December 2004 Indian Ocean tsunami, Earthquake Spectra 22 (S3), S475-S493.

Malik, J.N., Murty, C.V.R., and RAI, D.C. (2006), Landscape changes in the Andaman and Nicobar islands (India) after the December 2004 great Sumatra earthquake and Indian Ocean tsunami, Earthquake Spectra 22 (S3), S43-S66. 
Maramai, A. and Tinti, S. (1997), The 3 June 1994 Java tsunami: A post-event survey of the coastal effects, Natural Hazards 15, 31-49.

Melekestsev, I.V. (1980), Volcanism and Relief Formation, Nauka, Moscow, 212 pp. (in Russian).

Minoura, K., Gusiakov, V.G., Kurbatov, A., Takeuti, S., Svendsen, J.I., Bondevik, S., and Oda, T. (1996), Tsunami sedimentation associated with the 1923 Kamchatka earthquake, Sed. Geol. 106, 145-154.

NGDC database-National Geophysical Data Center Tsunami Database, http://www.ngdc.noaa.gov/hazard/ tsu_db.shtml (last accessed May 2008).

Okal, E.A., Sladen, A., and Okal, E.A.-S. (2006), Rodrigues, Mauritius, and Réunion islands; Field survey after the December 2004 Indian Ocean tsunami, Earthquake Spectra 22 (S3), S241-S261.

Pelinovsky, E., Troshina, E., Golinko, V., Osipenko, N., and Petrukhin, N. (1999), Runup of tsunami waves on a vertical wall in a basin of complex topography, Phys. Chem. Earth (B) 24(5), 431-436.

Rabinovich, A.B., Lobkovsky, L.I., Fine, I.V., Thomson, R.E., Ivelskaya, T.N., and Kulikov, E.A. (2008), Nearsource observations and modeling of the Kuril Islands tsunamis of 15 November 2006 and 13 January 2007, Adv. Geosci. 14, 105-116.

Shepard, F.P., Macdonald, G.A., and Cox, D.C. (1950), The tsunami of April 1, 1946, Hawaii, Calif. Univ., Scripps Inst. Oceanography Bull. 5, 391-528.

Shi, S., Dawson, A. G., and Smith, D. E. (1995), Coastal sedimentation associated with the December 12th 1992 tsunami in Flores, Indonesia. In Recent Tsunamis (eds. Satake, K., and Imamura, K., Pure. Appl. Geophys. $144,525-536$.

Snow, H.J., In Forbidden Seas. Recollections of Sea-otter Hunting in the Kurils, (London, E. Arnold, 1910).

Soloviev, S.L. (1972), Recurrence of earthquakes and tsunamis in the Pacific Ocean, Volny Tsunami, Trudy Sakhnii 29, 7-47 (in Russian).

Song, T.A. and Simons, M. (2003), Large trench-parallel gravity variations predict seismogenic behavior in subduction zones, Science 301, 630, doi: 10.1126/science.1085557.

Tanioka, Y., Hasegawa, Y., and Kuwayama, T. (2008), Tsunami waveform analyses of the 2006 underthrust and 2007 outer-rise Kurile earthquakes, Advances in Geosciences 14, 129-134.

Umitsu, M., Tanavud, C., and PatanaKanog, B. (2007), Effects of landforms on tsunami flow in the plains of Banda Aceh, Indonesia, and Nam Khem, Thailand, Marine Geology 242, 141-153.

VALLÉE, M. (2006) http://geoazur.unice.fr/SEISME/KURIL151106/note1.html (last accessed May 2008)

VALLÉE, M. (2007) http://geoazur.unice.fr/SEISME/KURIL130107/note1.html (last accessed May 2008)

YAGI, Y. (2006) http://www.geo.tsukuba.ac.jp/press_HP/yagi/EQ/Chishima/ (last accessed May 2008)

YAGI, Y. (2007) http://www.geo.tsukuba.ac.jp/press_HP/yagi/EQ/2007Chishima/ (last accessed May 2008).

Yeh, H., Titov, V., Gusiakov, V., Pelinovsky, E., Khramushin, V., and Kaistrenko, V. (1995), The 1994 Shikotan earthquake tsunamis, Pure. Appl. Geophys. 144(3/4), 855-874.

(Received January 1, 2008, accepted June 3, 2008)

To access this journal online:

www.birkhauser.ch/pageoph 